\title{
Using official map data on topography, wetlands and vegetation cover for prediction of stream water chemistry in boreal headwater catchments
}

\author{
J.-O. Andersson ${ }^{1}$ and L. Nyberg ${ }^{2}$ \\ ${ }^{1}$ Department of Biology, Karlstad University, Universitetsgatan 2, 65188 Karlstad, Sweden \\ ${ }^{2}$ Centre for Climate and Safety, Karlstad University, Universitetsgatan 2, 65188 Karlstad, Sweden
}

Received: 2 April 2008 - Published in Hydrol. Earth Syst. Sci. Discuss.: 29 May 2008

Revised: 14 April 2009 - Accepted: 21 April 2009 - Published: 27 April 2009

\begin{abstract}
A large part of the spatial variation of stream water chemistry can be related to inputs from headwater streams. In order to understand and analyse the dominant processes taking place in small and heterogeneous catchments, accurate data with high spatial and temporal resolution is necessary. In most cases, the quality and resolution of available map data are considered too poor to be used in environmental assessments and modelling of headwater stream chemistry. In this study 18 forested catchments $\left(1-4 \mathrm{~km}^{2}\right)$ were selected within a $120 \times 50 \mathrm{~km}$ region in the county of Värmland in western Sweden. The aim was to test if topographic and vegetation variables derived from official datasets were correlated to stream water chemistry, primarily the concentration of dissolved organic carbon (DOC), but also $\mathrm{Al}, \mathrm{Fe}$ and $\mathrm{Si}$ content. GIS was used to analyse the elevation characteristics, generate topographic indices, and calculate the percentage of wetlands and a number of vegetation classes. The results clearly show that topography has a major influence on stream water chemistry. There were strong correlations between mean slope and percentage wetland, percentage wetland and DOC, mean slope and DOC, and a very strong correlation between mean topographic wetness index (TWI) and DOC. The conclusion was that official topographic data, despite uncertain or of low quality and resolution, could be useful in the prediction of headwater DOC-concentration in boreal forested catchments.
\end{abstract}

Correspondence to:

J.-O. Andersson

(jan-olov.andersson@kau.se)

\section{Introduction}

The chemistry of headwater streams is influenced by several landscape factors which are related to geology, topography, climate, and vegetation. During the 20th century, human impacts have also been significant, even for the smallest stream systems. These include direct impacts from land use measures and indirect impacts from atmospheric deposition.

In Nordic boreal forests, some landscape factors are especially important for the development of stream water chemistry. One of these is the dominance of acidic bedrock (granite and gneiss), which results in acid-sensitive waters with a low content of dissolved substances. Another factor is the multitude of wetlands, which increase dissolved organic matter, resulting in increased natural acidity. Andersson and $\mathrm{Ny}-$ berg (2008), for example, reported that approximately $60 \%$ of 68 randomly selected boreal headwater streams had a water colour above $100 \mathrm{mg} \mathrm{Pt} / \mathrm{l}$ at medium flow. This corresponds to the highest of five classes in the Environmental Quality Criteria established by the Swedish Environmental Protection Agency (SNV, 2003).

Severe acidification has been a dominant environmental condition in forested areas in Sweden and Norway for several decades. Separating anthropogenic causes from natural acidity has recently become a focus (SEPA, 2003), and there is an interest in understanding how landscape factors influence stream water chemistry, especially those factors that govern stream acidity.

The forested landscape in Sweden also experiences a longterm increase in dissolved organic matter. This could be exemplified by the trend for absorbance in River Klarälven

Published by Copernicus Publications on behalf of the European Geosciences Union. 


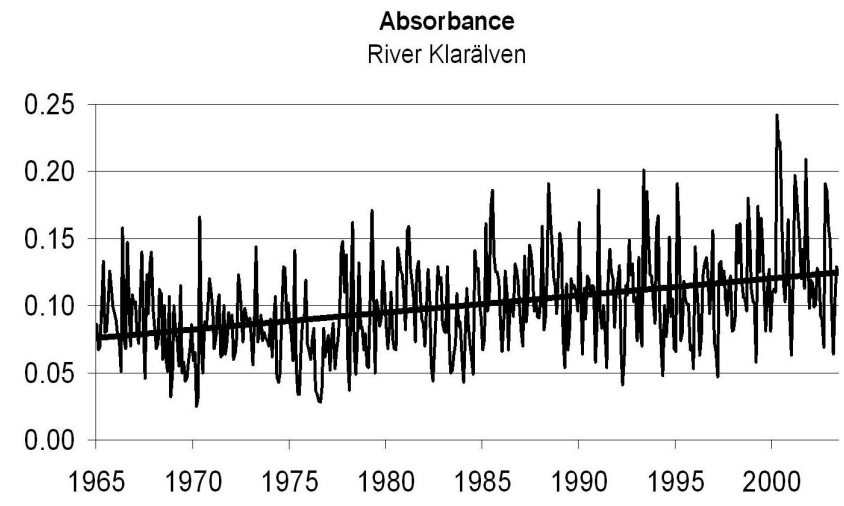

Fig. 1. Absorbance measured monthly at Edsforsen in River Klarälven, Sweden, between 1965 and 2003. The catchment area upstream the sampling point is $8570 \mathrm{~km}^{2}$ (Monitoring data from the Swedish University of Agricultural Sciences, www.ma.slu.se)

(Fig. 1), which is a larger river situated adjacent the region studied in this paper. The increase has been $+50 \%$ over 40 years. The reason for the increase in this particular case is not fully understood, but climate change (Clair et al., 1994; Freeman et al., 1995; Moore, 1998; Tranvik et al., 2002; Worall et al., 2003; Löfgren et al., 2003) and intensified forestry (Rosén et al., 1996; Lundin, 1999) are suggested as factors. A third potential factor can be decreased deposition of sulphur (Monteith et al., 2007).

There seems to be a gap between hydrological processoriented research and the institutions that are dependent on research methods and results for their work of solving regional and national environmental problems. The process knowledge is mostly available from studies of soil profiles, hillslopes or smaller catchments, whereas the need for management tools is most obvious at a larger scale. One reason for the dominance of small-scale studies is the large spatial and temporal variability of factors that determine hydrology and hydrochemistry. Wolock et al. (1997), for example, showed that stream chemistry variability significantly decreased beyond catchment sizes of $3-4 \mathrm{~km}^{2}$. Another reason is the lack of tools to measure at larger scales. Hooper (2001), for example, concluded that "the instruments measure at a scale of decimetres when we need to understand the landscape at the scale of hectares or square kilometres". A third reason might be that research on boreal forest hydrology has been closely linked to acidification research for several decades, and that most of the acidification problems are found at higher elevations near small headwater streams.

There is a need for simpler, less time-consuming and less costly methods to predict headwater chemistry to evaluate the natural state of water quality, in order to make correct decisions for protection and restoration measures (SNV, 2003).

To reduce the gap between small-scale process knowledge and demands for better understanding at larger scales, one can study smaller elements that are aggregated into larger systems (Sivapalan and Kalma, 1995; Blöschl and Sivapalan, 1995). In doing this up-scaling, it is necessary to integrate new tools and data, such as the latest developments of GIS and official regional or national databases, into the analysis. For hydrology and hydrochemistry, the process knowledge gained from hillslope studies and small experimental catchments first needs to be evaluated at the next larger scale, i.e. larger first-order and second-order streams. Blöschl (2001) suggested that instead of trying to capture everything when upscaling it would be better to identify dominant processes that control hydrological response at different scales, and then develop models to focus on these dominant processes. When increasing scale, in-stream and hyporheic processes will be more important, and a crucial scale-step is when the streams flow into the first lake, which, depending on size, could have a large impact on hydrology and hydrochemistry.

\subsection{Topography}

Research results from past twenty years clearly show an influence of topography and wetland on stream water chemistry. The influence of topography is important because it controls the water subsurface contact time (Beven and Kirkby, 1979; Wolock et al., 1990; Dillon and Molot, 1997; McGuire et al., 2005). Since the beginning of 1990's many methods for deriving attributes from elevation data have been developed for use in hydrological applications. These attributes can be divided in two groups: primary and secondary topographic attributes.

Topography is of great significance in hydrology, affecting soil water content, flowpaths and residence times (Nyberg, 1995), and subsequently the chemical composition of surface waters (Beven, 1986; Wolock et al., 1989). Mean slope, based on a DEM with $50 \mathrm{~m}$ grid, was a variable that correlated with headwater chemistry in a previous study in the same region as in this paper (Andersson and Nyberg, 2008).

A secondary attribute is the topographic wetness index (TWI), $\ln (a / \tan \beta)$, where $a$ is the upslope area per unit contour length and $\tan \beta$ is the local slope (Beven and Kirkby, 1979; Quinn et al., 1995). The TWI represents the wetness distribution in a catchment, and it has frequently been used in modelling. A high value of the index means that the groundwater table is likely to be close to the ground surface. Subsequently, wetlands occur in areas with high values of the topographic wetness index, and it would be possible to predict locations of these by calculating topographic wetness indices over catchments. The possibility of doing this successfully, however, depends on the relation between the spatial resolution of the data used in the index calculation and the typical length scales of the topography in the catchment (Rodhe and Seibert, 1999). The scale and terrain roughness of the analysed landscape and the resolution of the elevation data sets limits for the quality of the result (Moore et al., 1993; Wolock et al., 1994; Zhang and Montgomery, 1994; Tarboton, 1997). The calculation of wetness indices is, however, sensitive to 


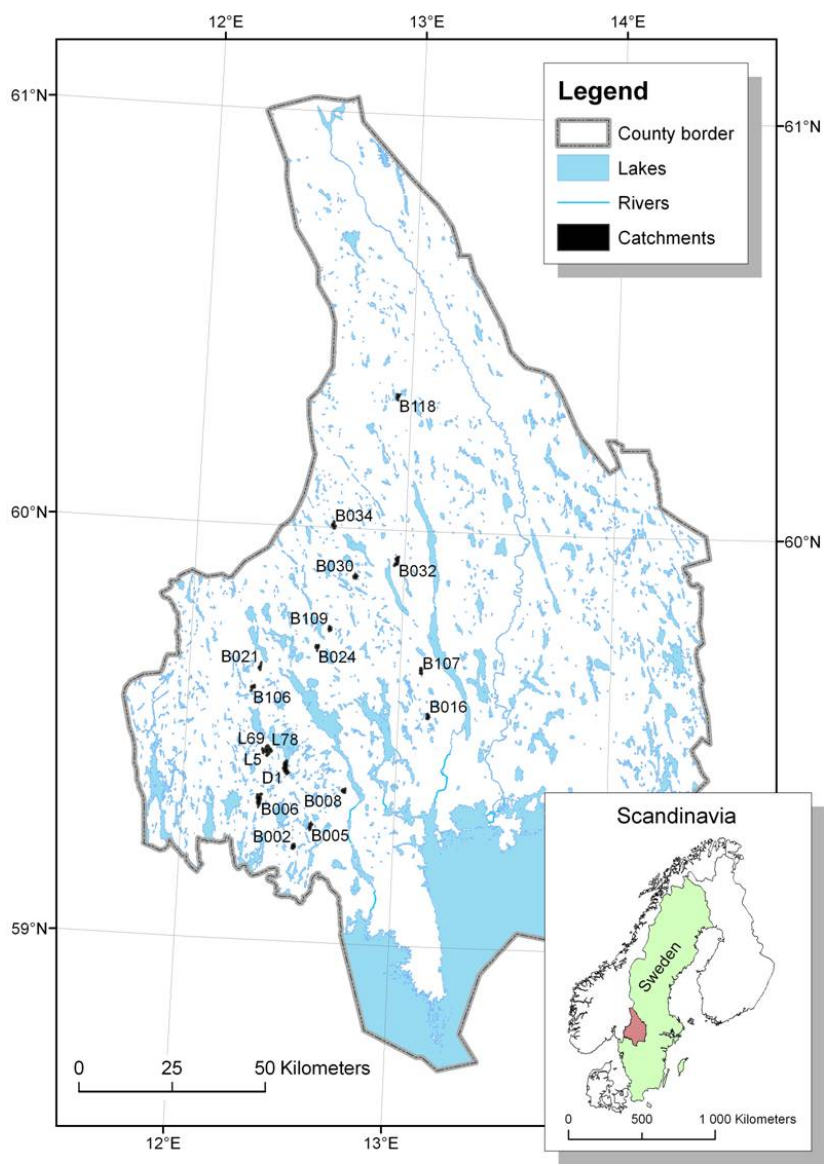

Fig. 2. Study region with 18 catchments in a $120 \times 50 \mathrm{~km}$ area in the county of Värmland, Sweden.

the algorithm that is used (Güntner et al., 2004). The calculation of the upslope contributing area is especially crucial for the resulting pattern of saturated areas.

\subsection{Wetlands, vegetation cover and dissolved organic matter}

In the Swedish boreal landscape, mires, divided into bogs, fens and mixed mires, is the most common wetland group (Löfroth, 1991). There are also a number of sub-divisions of mire types that are classified by areal photo interpretation and presented on vegetation maps. The occurrence of mires in boreal headwater catchments has been shown to be significantly correlated with stream chemistry. Processes in peat and other frequently saturated organic soils produce humic substances that are transported to streams (Clair et al., 1994; Dillon and Molot, 1997; Mulholland and Kuenzler, 1979; Eckhardt et al., 1990; Koprivnjak and Moore, 1992; Hope et al., 1994; Mulholland, 1997). Hemond (1990) suggested that the most important processes take place in the riparian zone, and that they depend on stream flow generation. These results were supported by Bishop et al. (1994) but questioned by Köhler et al. (1999), who concluded that the question of how organic acids enter streams still was open. Andersson and Nyberg (2008) concluded, from a study of 68 headwater streams, that it did not seem possible to predict humic substances in headwater streams by simply looking at the occurrence and locations of wetlands that are shown on official maps. Many small or hidden wetlands, or cryptic wetlands (Creed et al., 2003), with shallow peat cover are not shown on official topographic maps because they are difficult or impossible to locate on aerial photos. Still, they are possible sources of production of dissolved organic matter in headwater catchments. There are also vegetation types other than mires that may include thin layers of peat, i.e. moist and wet coniferous and deciduous forest. The distributions of these are normally only included in vegetation cover maps.

\subsection{Objectives}

The main objective of this study was to analyse the relationships between 1) topography and 2) wetland and vegetation cover, as represented by available official landscape data (topographic maps, a digital elevation model and vegetation data), versus water chemistry in boreal headwater streams in western Sweden. The aim was to determine "dominant landscape variables" that control the transport of both dissolved organic matter, which is closely associated with natural acidification, and metals such as Fe and Al. This study, which included catchments on the scale of $1-4 \mathrm{~km}^{2}$, was a follow-up of an earlier study with catchment sizes $0.5-1.5 \mathrm{~km}^{2}$ (Andersson and Nyberg, 2008).

\section{Study region}

The 18 studied catchments were located within a $120 \times 50 \mathrm{~km}$ region in the county of Värmland in western Sweden, between latitude 59 and 61 degrees $\mathrm{N}$ and longitude 12 and 14 degrees E (Fig. 2).

The dominant landform in the region where the catchments are located is a hilly relief with some occurrence of faults and bare bedrocks in the south, and higher but gentler hills in the north. The igneous bedrock consists mainly of acidic granites and gneisses with local occurrence of outcrops of magmatic hyperite and other rock types (Lundegårdh, 1995). The dominant soil type is till (>65\%), peat $(\sim 20 \%)$ and some areas with sand and silt. The region contains lakes and wetlands while only a small part $(<10 \%)$ is covered by farmland. The average elevation is approx. $200 \mathrm{~m}$ a.s.l. and the highest marine shoreline lies between 170 and $210 \mathrm{~m}$ a.s.l. within the region (Lundqvist, 1958, 1961). The annual mean temperature is $3-5^{\circ} \mathrm{C}$, precipitation $800-900 \mathrm{~mm}$, runoff $400-450 \mathrm{~mm}$ and evapotranspiration $400-450 \mathrm{~mm}$. The precipitation normally falls as snow between November and mid March. The peak runoff normally occurs during the snowmelt period (Raab and Vedin, 
Table 1. Catchment and topographic characteristics.

\begin{tabular}{lcccccc}
\hline & $\begin{array}{c}\text { Area } \\
{\left[\mathrm{km}^{2}\right]}\end{array}$ & $\begin{array}{c}\text { Lowest elevation } \\
{[\mathrm{m} \text { a.s.1.] }}\end{array}$ & $\begin{array}{c}\text { Highest elevation } \\
{[\mathrm{m} \text { a.s.l. }]}\end{array}$ & $\begin{array}{c}\text { Mean elevation } \\
{[\mathrm{m} \text { a.s.l. }]}\end{array}$ & $\begin{array}{c}\text { Mean slope } \\
{[\%]}\end{array}$ & Mean TWI \\
\hline Mean & 1.56 & 172 & 282 & 236 & 8.9 & 11.8 \\
Std dev & 0.78 & 45 & 54 & 51 & 2.8 & 0.3 \\
Min & 0.97 & 86 & 201 & 150 & 4.1 & 11.2 \\
Max & 3.81 & 244 & 400 & 316 & 14.7 & 12.4 \\
$\mathrm{n}$ & 18 & 18 & 18 & 18 & 18 & 18 \\
\hline
\end{tabular}

1995). Coniferous forests (Picea abies and Pinus sylvestris) dominates. Within the region, forestry is main direct human impact, but the studied catchments have little or no impact from recent forestry. The region has also suffered from deposition of sulphur and nitrogen (Lundström et al., 1998). Characteristics of the studied catchments are shown in the result chapter (Table 1.).

\section{Methods}

1:250000 and 1:100000 scale official topographic maps from the Swedish Land Survey were used to delimit a study region within the western part of the county of Värmland. Eighteen first-order streams were selected within the region for this study. The selected streams were part of two previous studies: 14 of the catchments were taken from a study of 76 first-order streams, described by Andersson and Nyberg (2008). The 14 largest of the 76 catchments were selected from that study. The other four were taken from a hydrological restoration project called "The Laskerud Project" (unpublished data). The streams were first or second order. No arable or urban land was included in the 18 catchments. Forestry occurs in the catchments but was estimated not to be of the magnitude of influence to be considered in this study.

\subsection{Spatial datasets}

1:50000 and 1:20000 scale official topographic maps from the Swedish Land Survey were scanned and used for delineation of the catchments. Streams, wetlands and contour lines were digitized. The contours were used for delineation of catchments. The topographic maps were rather coarse in relation to the size of the catchments in this study. The maps show larger wetlands ( $>0.5 \mathrm{ha}$ ) and the generalization is rather strong.

An official $50 \mathrm{~m}$ resolution digital elevation model (DEM) and vegetation data were obtained from the Swedish Land Survey. The DEM has a mean elevation error of $2.5 \mathrm{~m}$. The vegetation data was produced by visual interpretation of infrared aerial photos $(4600 \mathrm{~m})$ and has comparatively high spatial accuracy.
Data on soil (type, texture) and bedrock (type) were not included in the study as spatial datasets, since the available official maps have too low accuracy and spatial resolution. In the region the bedrock and quaternary deposits are, however, fairly homogenous. Furthermore, data on vegetation cover generally reflects the distribution of soil types well (Moore et al., 1991).

\subsection{GIS analysis}

ArcInfo GIS was used for calculations of layers for area, elevation, slope and TWI for each catchment. The calculation of the upslope area was based on the commonly used deterministic 8 (D8) model (O'Callagan and Mark, 1984) for flow over a terrain surface represented by the DEM. The mean value of the slope and TWI was calculated for each catchment and used in the statistical analysis.

The percentage of each vegetation type within the catchments was calculated. The digitized wetlands from the 1:50,000 scale maps were managed in the same way and compared with the mire types extracted from the vegetation data. The mires were classed into fens, bogs and mixed mires.

\subsection{Water sampling and chemical analysis}

Water samples were collected at the outlet of each catchment four times at different flow situations during different seasons: summer low flow, summer medium flow (\#1), autumn medium flow (\#2) and spring high flow. Fourteen of the streams were sampled in 1998 and 1999 during four sampling events. The chemistry data from the four streams in the Laskerud Project were selected from a time series from 2003 and 2004. The selection was based on season and specific discharge. The filtered samples were kept dark and cool until the concentration of DOC [mg/l] was determined. The instrument used for measuring the DOC-concentration was a Schimadzu 500 carbon-analyser. Fe, Al and Si were analysed with ICP-OES (Varian).

The runoff was estimated by simple methods (bucket or float) when the samples were taken. The specific runoff was in average $0.8 \mathrm{l} / \mathrm{s} / \mathrm{km}^{2}$ at the low flow situation, $13 \mathrm{l} / \mathrm{s} / \mathrm{km}^{2}$ at the medium flow \#1 situation, $11,1 / \mathrm{s} / \mathrm{km}^{2}$ at the medium 
Table 2. Descriptive statistics for wetland coverage estimated from topographic maps and from the vegetation database.

\begin{tabular}{lccccc}
\hline & Topo.map & \multicolumn{4}{c}{ Vegetation data } \\
\hline$\%$ & & Fen & Bog & Mixed & Sum \\
Mean & 7.7 & 1.6 & 2.3 & 3.1 & 7.0 \\
Std dev & 7.5 & 1.5 & 1.9 & 2.4 & 6.2 \\
Min & 0.5 & 0 & 0 & 0.2 & 0.2 \\
Max & 20.3 & 5.1 & 10.9 & 8.6 & 21.1 \\
$\mathrm{n}$ & 18 & 18 & 18 & 18 & 18 \\
\hline
\end{tabular}

flow \#2 situation and $30 \mathrm{l} / \mathrm{s} / \mathrm{km}^{2}$ at the high flow situation. During the high flow sampling round, seven streams were not sampled due to snow covered roads that made the sites inaccessible.

\subsection{Statistical analysis}

PCA analysis was initially performed to study the overall relations between topographic, wetland and vegetation variables. Correlation (Pearson) and linear regression analyses were then performed in order to investigate the covariation between landscape variables and water chemistry at different flow situations.

\section{Results}

\subsection{Topographic characteristics}

The mean size of the 18 catchments was $1.56 \mathrm{~km}^{2}$ (Table 1). Catchment L5 has been selected to demonstrate the spatially distributed data used in the analysis (Fig. 3a-c). L5 was the catchment with highest percentage of wetland, $20 \%$. It was also the catchment with lowest mean slope, $4.1 \%$. The topographic wetness index for single $50 \times 50 \mathrm{~m}$ cells ranged from 9.6 to 19.1 with a mean of 12.4 .

Mean slope and mean topographic wetness index were strongly (negatively) correlated to each other, which was expected since the calculation of TWI includes the slope in the denominator. The correlation coefficient of -0.95 indicated that the slope has a dominant influence in the TWI, compared to the upstream drainage area per contour length $a$.

\subsection{Wetland characteristics}

In average $7 \%$ of the total area of the 18 studied catchments were covered with wetland (Table 2). The wetland percentage on the 1:50,000 scale maps was $0.7 \%$ larger than the percentage in the vegetation data. About $40 \%$ of the wetland was mixed mire according to the vegetation data.

There were only small differences in the distribution and location of wetlands in the two types of data sources. The errors were mainly caused by misinterpretations between wet

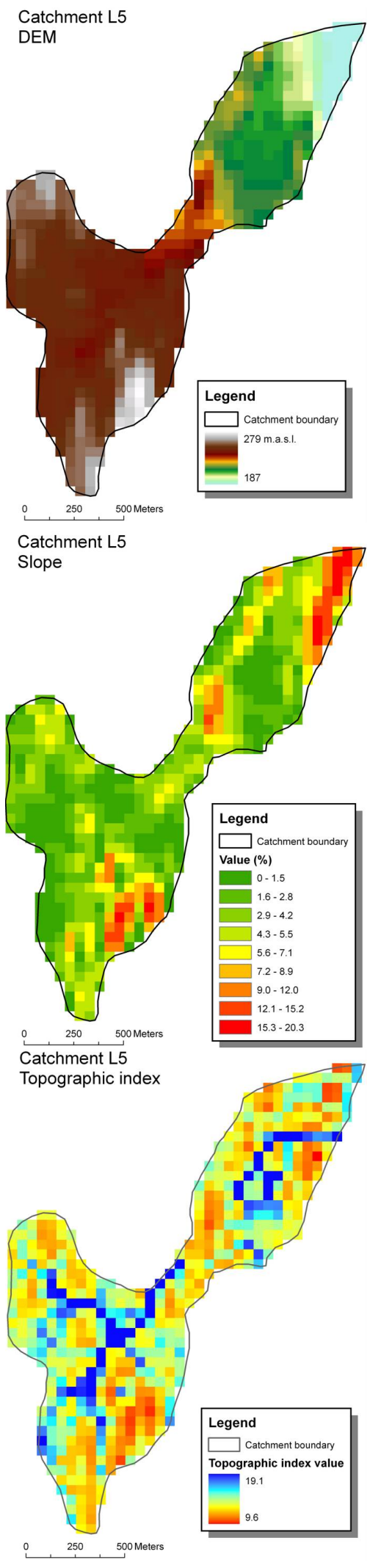

Fig. 3. Topographic description of example catchment L5. (a) Elevation [m a.s.1.], (b) Slope [\%] and (c) Topographic wetness index. 
Table 3. Vegetation types, total percentages (for all 18 catchments) and descriptions.

\begin{tabular}{lcl}
\hline Vegetation type & Area [\%] & Description \\
\hline 1 Coniferous forest, dry & 8.1 & Bare rocks, thin soil layer, lichens, mosses, mainly pines \\
2 Coniferous forest, mesic & 76.8 & Mosses, dwarf shrubs, blueberry, mainly spruce \\
3 Coniferous forest, moist & 4.1 & Mosses incl. forest Sphagna, dwarf shrubs, mainly spruce \\
4 Coniferous forest, wet & 1.7 & Mosses, low herbs, dwarf shrubs, spruce, waterlogged \\
5 Coniferous forest, mire & 2.7 & Fen or bog, Sphagnum spp, Ledum, pine and spruce \\
6 Deciduous forest, mesic & 0.2 & Cultivated soil, birch, aspen and other deciduous species \\
7 Deciduous forest, wet & 0.1 & Thick forest with birch, alder, viden, wet hummocky ground \\
8 Deciduous forest, mire & 0.2 & Fen, sparse vegetation, birch and viden \\
9 Dwarf shrub hummock mire & 0.9 & Hummocky peat, Sphagnum spp, shrubs and dwarf pines \\
10 Mire of lawn type & 2.0 & Fen or bog, lawn-like vegetation \\
11 Mire of carpet type & 1.1 & Fen or bog, wet, soft, carpet-like vegetation \\
12 Mire of peat mud type & 0.1 & Fen or bog, mudbottom vegetation, flarks \\
13 Plantation & 0.7 & Tree plantation on former open land, spruce or pine \\
14 Water & 0.9 & Open water or water with sparse vegetation \\
15 Others & 0.3 & Meadow, arable land, grassland, garden etc. \\
\hline
\end{tabular}

Table 4. Occurrence of vegetation types in the catchments.

\begin{tabular}{|c|c|c|c|c|c|c|c|c|c|c|c|c|c|c|c|c|}
\hline \multirow[b]{2}{*}{ Catchment } & \multicolumn{16}{|c|}{ Vegetation type } \\
\hline & 1 & 2 & 3 & 4 & 5 & 6 & 7 & 8 & 9 & 10 & 11 & 12 & 13 & 14 & 15 & $n$ \\
\hline B002 & $\times$ & $x$ & & $x$ & & & & & & & $x$ & & $x$ & & & 5 \\
\hline B005 & $x$ & $x$ & $\times$ & $x$ & $x$ & $x$ & & $x$ & & & $x$ & & $x$ & $x$ & $x$ & 11 \\
\hline B006 & $x$ & $x$ & $x$ & $x$ & $x$ & & $x$ & & $x$ & $x$ & $x$ & & $x$ & $x$ & $\times$ & 12 \\
\hline B008 & $x$ & $x$ & $x$ & $x$ & $x$ & & & & & & & & & & & 5 \\
\hline B016 & $x$ & $\times$ & $x$ & $x$ & $x$ & & & $x$ & $x$ & $x$ & $x$ & & & & & 9 \\
\hline B021 & & $x$ & $\times$ & & $x$ & $\times$ & $x$ & $x$ & & $x$ & $x$ & & & & & 8 \\
\hline B024 & $\times$ & $x$ & $x$ & $x$ & $x$ & & & & & $x$ & & $x$ & & $x$ & & 8 \\
\hline B030 & & $x$ & $x$ & & $x$ & $\times$ & & & $x$ & & & & $x$ & & & 6 \\
\hline B032 & & $x$ & $x$ & $\times$ & $x$ & & & $x$ & $\times$ & $x$ & $\times$ & & & & & 8 \\
\hline B034 & $\times$ & $x$ & $x$ & $x$ & $x$ & $\times$ & & & & $\times$ & & & & & $\times$ & 8 \\
\hline B106 & $x$ & $x$ & $x$ & $x$ & $x$ & $x$ & & $x$ & $x$ & & & & $x$ & $x$ & $x$ & 11 \\
\hline B107 & $\times$ & $x$ & $\times$ & $\times$ & $x$ & & & & & $\times$ & $x$ & & & & & 7 \\
\hline B109 & & $x$ & $x$ & & $x$ & & & & $x$ & & $x$ & & & & & 5 \\
\hline B118 & & $x$ & $x$ & & $x$ & & & & $x$ & & $x$ & & $x$ & & $x$ & 7 \\
\hline D1 & $\times$ & $\times$ & $\times$ & $\times$ & $x$ & & & & $x$ & $\times$ & $x$ & $x$ & & $x$ & $x$ & 11 \\
\hline L5 & $\times$ & $x$ & $x$ & $x$ & $x$ & & $\times$ & $\times$ & $x$ & $x$ & $\times$ & & & $x$ & $\times$ & 12 \\
\hline L69 & $x$ & $x$ & $x$ & $x$ & $x$ & & $x$ & $x$ & $x$ & & $\times$ & & & $x$ & & 10 \\
\hline L78 & & $x$ & $\times$ & $\times$ & $x$ & & $x$ & $x$ & $\times$ & $x$ & $\times$ & & & $\times$ & $x$ & 11 \\
\hline$n$ & 12 & 18 & 17 & 14 & 17 & 5 & 5 & 8 & 11 & 10 & 13 & 2 & 6 & 8 & 8 & \\
\hline
\end{tabular}

coniferous forest and coniferous mire. There is no distinction between mire classes in the topographic map. The map examples show the distribution of fen, bog and mixed mire (Fig. 4) and the mire types represented in the vegetation database (Fig 5) in catchment L5.

\subsection{Vegetation characteristics}

The vegetation database included 22 vegetation types within the catchments, of which the 7 types with smallest percentage were merged and categorized as "others". The catchments were dominated by mesic coniferous forest $(77 \%)$ of total area. Dry coniferous forest covered $8.1 \%$ and moist coniferous forest $4.1 \%$. Of the mire vegetation types the lawn 


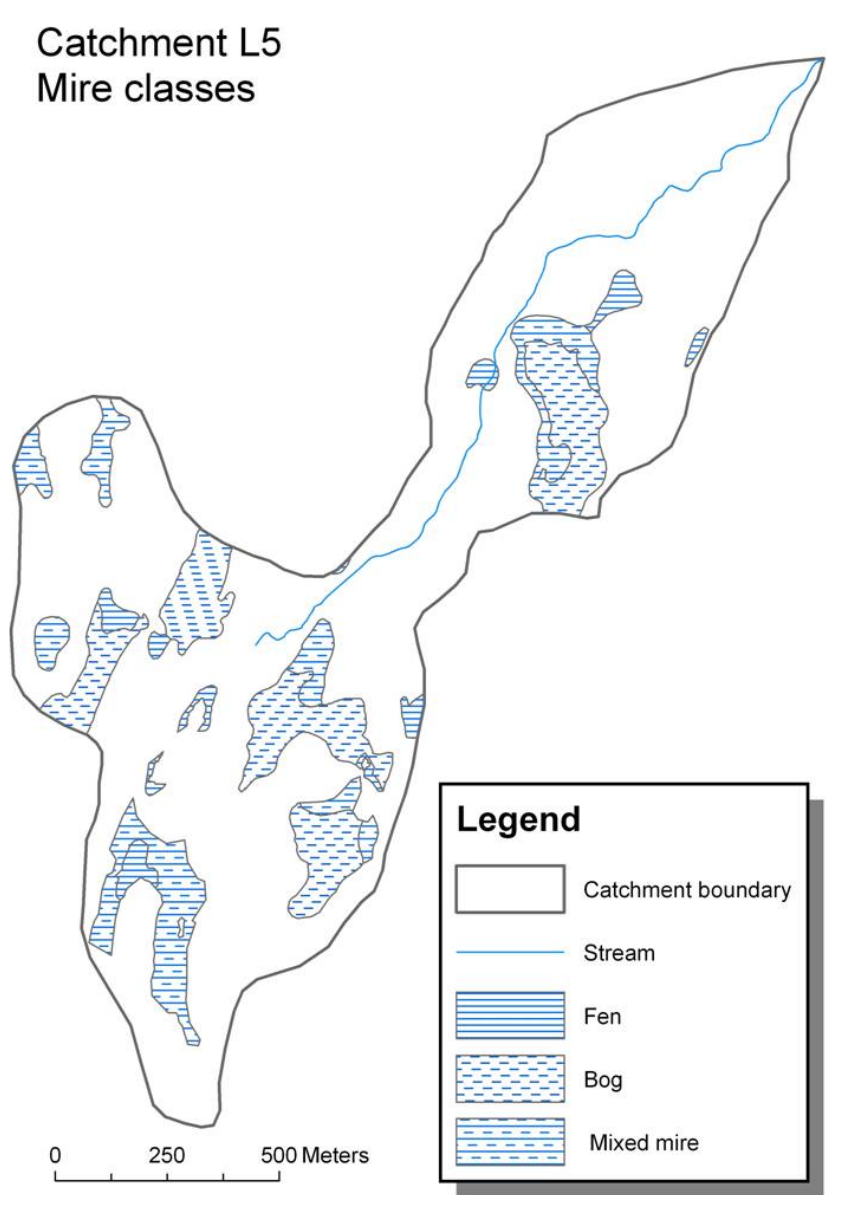

Fig. 4. Mire classes in catchment L5.

type $(2.0 \%)$ and carpet type $(1.1 \%)$ was most common (Table 3). In Table 4 the occurrences of the different vegetation types in each catchment are listed.

There was a large heterogeneity regarding vegetation types within and between the catchments (Table 4). Catchment B008 and B109 only comprised five vegetation types while catchment B006 and L5 had twelve. The table also shows the frequency of the vegetation types. Mesic coniferous forest was found in every catchment. Moist coniferous forest was found in all but one, while others were less frequent.

\subsection{Chemical characteristics}

DOC-concentration was used as a measure of dissolved organic matter. The DOC-concentration in the studied catchments were relatively high (Table 5), and the temporal and spatial variations were large (Fig. 7). The highest levels were found for the low and autumn medium flow samplings. The high and summer medium flow samplings had lower levels of DOC.

Fe (Fig. 6) and Al were correlated to DOC (Table 6), and had similar seasonal patterns as DOC. Si, which is a measure

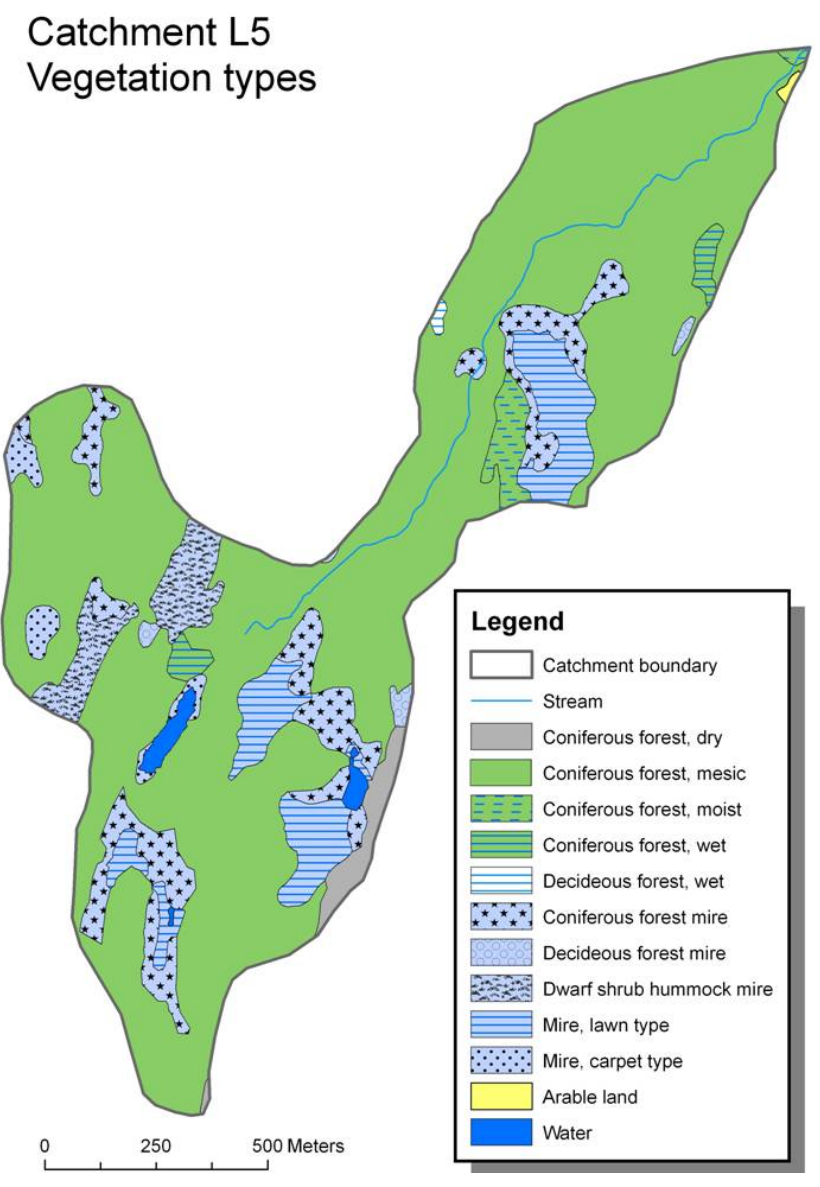

Fig. 5. Vegetation types in catchment L5.

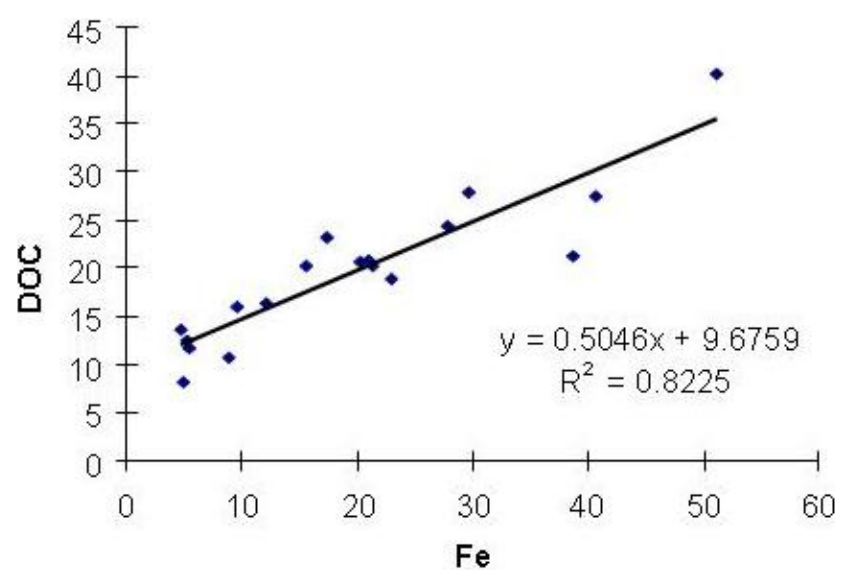

Fig. 6. Regressions showing the significant relationship between iron and DOC in the medium \#1 flow situation. Units for DOC is $\mathrm{mg} / \mathrm{l}$ and for $\mathrm{Fe} \mu \mathrm{mol} / \mathrm{l}$.

of silicate weathering, had highest concentrations during the autumn medium flow and lowest during the spring flood.

The greatest temporal variability was found in catchment B021 where the DOC-concentration ranged from $15.9 \mathrm{mg} / \mathrm{l}$ 
Table 5. Descriptive statistics for stream chemistry for four flow situations: low flow (L), medium flow (M1 and M2) and high flow (H). The unit for DOC is $\mathrm{mg} / \mathrm{l}$ and for $\mathrm{Al}, \mathrm{Fe}$ and $\mathrm{Si}$ it is $\mu \mathrm{mol} / \mathrm{l}$.

\begin{tabular}{lcccccccccccccccc}
\hline & \multicolumn{4}{c}{ DOC } & \multicolumn{1}{c}{$\mathrm{Al}$} & \multicolumn{4}{c}{$\mathrm{Fe}$} & \multicolumn{4}{c}{$\mathrm{Si}$} \\
\hline & $\mathrm{L}$ & M1 & M2 & H & L & M1 & M2 & H & L & M1 & M2 & H & L & M1 & M2 & H \\
Mean & 18.8 & 19.7 & 14.4 & 12.6 & 18.8 & 19.6 & 14.9 & 9.1 & 26.4 & 19.4 & 12.2 & 8.3 & 106.0 & 105.2 & 115.1 & 81.8 \\
Std dev & 8.2 & 7.5 & 4.2 & 2.6 & 10.7 & 8.8 & 5.3 & 1.9 & 18.5 & 13.0 & 6.6 & 4.0 & 30.7 & 26.5 & 16.6 & 11.6 \\
Min & 6.8 & 8.2 & 7.3 & 7.9 & 3.9 & 5.9 & 6.9 & 5.8 & 2.5 & 4.7 & 2.7 & 2.6 & 54.4 & 70.0 & 93.5 & 68.2 \\
Max & 32.6 & 40.1 & 22.8 & 16.7 & 36.0 & 42.1 & 23.6 & 11.9 & 62.8 & 51.2 & 25.0 & 16.1 & 150.4 & 167.8 & 152.6 & 102.1 \\
$n$ & 18 & 18 & 18 & 11 & 14 & 18 & 17 & 11 & 14 & 18 & 17 & 11 & 13 & 17 & 17 & 11 \\
\hline
\end{tabular}

Table 6. Pearson correlations between the measured chemical constituents at medium flow \#1 (M\#1) and high flow (H). $n=18$ for M\#1 and $n=11$ for $\mathrm{H}$. The strongest correlations are highlighted with bold numbers. $(* p<0.05, * * p<0.01)$.

\begin{tabular}{|c|c|c|c|c|c|c|}
\hline & DOC (M\#1) & $\mathrm{DOC}(\mathrm{H})$ & $\mathrm{Al}(\mathrm{M} \# 1)$ & $\mathrm{Al}(\mathrm{H})$ & $\mathrm{Fe}(\mathrm{M} \# 1)$ & $\mathrm{Fe}(\mathrm{H})$ \\
\hline DOC (M\#1) & 1.00 & & & & & \\
\hline $\mathrm{DOC}(\mathrm{H})$ & & 1.00 & & & & \\
\hline $\mathrm{Al}(\mathrm{M} \# 1)$ & $0.72 * *$ & & 1.00 & & & \\
\hline $\mathrm{Al}(\mathrm{H})$ & & 0.23 & & 1.00 & & \\
\hline $\mathrm{Fe}(\mathrm{M} \# 1)$ & $0.79 * *$ & & $0.52 *$ & & 1.00 & \\
\hline $\mathrm{Fe}(\mathrm{H})$ & & $0.68 *$ & & $0.67 *$ & & 1.00 \\
\hline $\mathrm{Si}(\mathrm{M} \# 1)$ & -0.13 & & -0.16 & & 0.19 & \\
\hline $\mathrm{Si}(\mathrm{H})$ & & 0.14 & & $0.62 *$ & & 0.49 \\
\hline
\end{tabular}

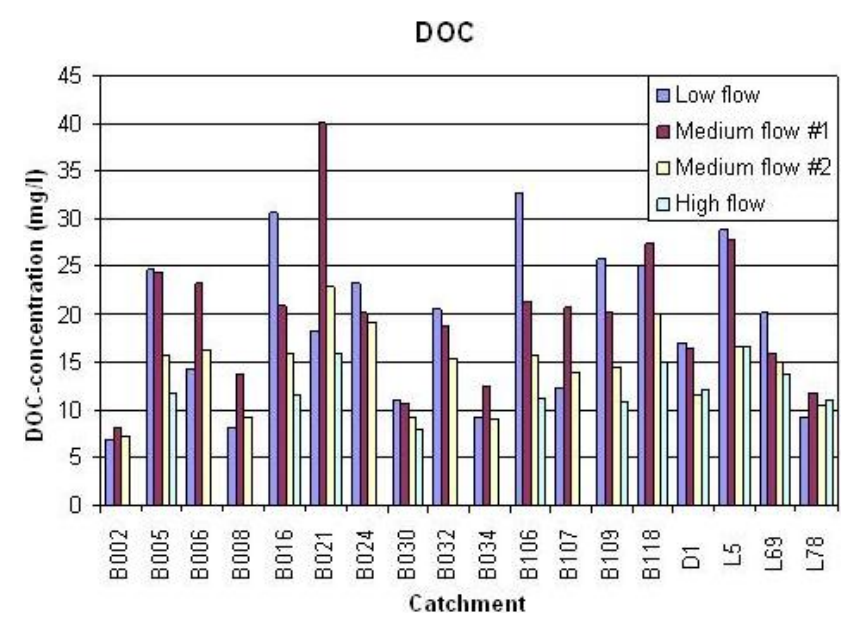

Fig. 7. DOC-concentrations for the 18 catchments during four flow situations.

at high flow to $40.1 \mathrm{mg} / \mathrm{l}$ at medium flow \#1. In B021 the mean DOC-concentration was $24.5 \mathrm{mg} / \mathrm{l}$ while it was as low as $7.3 \mathrm{mg} / \mathrm{l}$ in catchment $\mathrm{B} 002$.

\subsection{Relations between topography, wetland and vegeta- tion}

A principal component analysis (PCA) including all topographic and vegetation variables was carried out to investigate the relations between those two groups of variables (Fig. 8). The first principal component explained $40 \%$ of the total variation, and captured primarily the slope-related variation. The second component explained $22 \%$, and described the variation related to elevation.

There was a group of variables that contributed most to PC1: mean slope, mean TWI, total wetland and coniferous forest of mire type. These four variables were also strongly correlated to each other. A further analysis of the relation between coniferous mire type and total wetland showed that a rather stable proportion of $40 \%$ of the total wetland in each catchment was of coniferous mire type.

In PC2, dry coniferous forest had the strongest (negative) correlation with altitude. This was probably a side-effect of the weak correlation between altitude and latitude. The mean altitude of the catchments was slightly higher in the northern part of the study region, where the soil cover is somewhat deeper.

Not surprisingly there were several strong correlations between wetland, slope and TWI variables (Table 7, Fig. 9). 
Table 7. Correlations between topographic and wetland/mire class variables. $\mathrm{n}=18$. The strongest correlations are highlighted with bold numbers $(p<0.01)$.

\begin{tabular}{|c|c|c|c|c|c|c|c|}
\hline & Mean slope & Mean TWI & Wetland (Topo. map) & Wetland (Veg. data) & Fen & Bog & Mixed mire \\
\hline Mean slope & 1.00 & & & & & & \\
\hline Mean TWI & -0.95 & 1.00 & & & & & \\
\hline Wetland (Topo. Map) & -0.84 & 0.88 & 1.00 & & & & \\
\hline Wetland (Veg. Map) & -0.83 & 0.90 & 0.96 & 1.00 & & & \\
\hline Fen & -0.69 & 0.64 & 0.54 & 0.62 & 1.00 & & \\
\hline Bog & -0.66 & 0.68 & 0.86 & 0.86 & 0.47 & 1.00 & \\
\hline Mixed mire & -0.66 & 0.79 & 0.78 & 0.82 & 0.27 & 0.49 & 1.00 \\
\hline Coniferous forest mire & -0.72 & 0.79 & 0.84 & 0.92 & 0.59 & 0.82 & 0.70 \\
\hline Mire, lawn type & -0.61 & 0.63 & 0.70 & 0.64 & 0.23 & 0.64 & 0.54 \\
\hline Mire, carpet type & -0.58 & 0.62 & 0.56 & 0.62 & 0.63 & 0.34 & 0.60 \\
\hline Dwarf shrub hum. mire & -0.42 & 0.50 & 0.58 & 0.67 & 0.42 & 0.51 & 0.60 \\
\hline
\end{tabular}

Table 8. Correlations between topographical/wetland variables and stream chemistry variables (L represents low flow, M\#1 and M\#2 medium flow and $\mathrm{H}$ high flow). The strongest correlations are highlighted with bold numbers $(p<0.01)$.

\begin{tabular}{|c|c|c|c|c|c|c|c|c|}
\hline & & Mean slope & Mean TWI & Wetland (Topo. map) & Wetland (Veg. data) & Fen & Bog & Mixed mire \\
\hline \multirow[t]{2}{*}{$\mathrm{DOC}(\mathrm{L})$} & $r$ & -0.52 & 0.49 & 0.37 & 0.36 & 0.24 & 0.30 & 0.29 \\
\hline & $n$ & 18 & 18 & 18 & 18 & 18 & 18 & 18 \\
\hline \multirow[t]{2}{*}{$\mathrm{DOC}(\mathrm{M} \# 1)$} & $r$ & -0.73 & 0.76 & 0.58 & 0.69 & 0.56 & 0.36 & 0.71 \\
\hline & $n$ & 18 & 18 & 18 & 18 & 18 & 18 & 18 \\
\hline \multirow[t]{2}{*}{$\mathrm{DOC}(\mathrm{M} \# 2)$} & $r$ & -0.72 & 0.73 & 0.60 & 0.62 & 0.49 & 0.29 & 0.67 \\
\hline & $n$ & 18 & 18 & 18 & 18 & 18 & 18 & 18 \\
\hline \multirow[t]{2}{*}{ DOC $(\mathrm{H})$} & $r$ & -0.92 & 0.97 & 0.85 & 0.88 & 0.52 & 0.61 & 0.85 \\
\hline & $\mathrm{n}$ & 11 & 11 & 11 & 11 & 11 & 11 & 11 \\
\hline \multirow[t]{2}{*}{$\mathrm{Al}(\mathrm{L})$} & $r$ & -0.21 & 0.17 & 0.01 & -0.02 & -0.12 & -0.30 & 0.28 \\
\hline & $n$ & 15 & 15 & 15 & 15 & 15 & 14 & 15 \\
\hline \multirow[t]{2}{*}{$\mathrm{Al}(\mathrm{M \# 1)}$} & $r$ & -0.24 & 0.31 & 0.03 & 0.14 & 0.11 & -0.31 & 0.50 \\
\hline & $n$ & 18 & 18 & 18 & 18 & 18 & 17 & 18 \\
\hline \multirow[t]{2}{*}{$\mathrm{Al}(\mathrm{M \# 2})$} & $r$ & -0.16 & 0.22 & 0.02 & 0.05 & -0.03 & -0.40 & 0.48 \\
\hline & $n$ & 17 & 17 & 17 & 17 & 17 & 16 & 17 \\
\hline \multirow[t]{2}{*}{$\mathrm{Al}(\mathrm{H})$} & $r$ & -0.05 & 0.10 & -0.14 & -0.08 & -0.22 & -0.48 & 0.47 \\
\hline & $n$ & 11 & 11 & 11 & 11 & 11 & 10 & 11 \\
\hline \multirow[t]{2}{*}{$\mathrm{Fe}(\mathrm{L})$} & $r$ & -0.40 & 0.28 & 0.17 & 0.20 & 0.35 & 0.13 & 0.11 \\
\hline & $n$ & 15 & 15 & 15 & 15 & 15 & 14 & 15 \\
\hline \multirow[t]{2}{*}{$\mathrm{Fe}(\mathrm{M} \# 1)$} & $r$ & -0.58 & 0.60 & 0.39 & 0.52 & 0.40 & 0.19 & 0.61 \\
\hline & $n$ & 18 & 18 & 18 & 18 & 18 & 18 & 18 \\
\hline \multirow[t]{2}{*}{$\mathrm{Fe}(\mathrm{M \# 2})$} & $r$ & -0.67 & 0.69 & 0.56 & 0.61 & 0.39 & 0.28 & 0.73 \\
\hline & $n$ & 17 & 17 & 17 & 17 & 17 & 17 & 17 \\
\hline \multirow[t]{2}{*}{$\mathrm{Fe}(\mathrm{H})$} & $r$ & -0.81 & 0.86 & 0.71 & 0.77 & 0.45 & 0.42 & 0.82 \\
\hline & $n$ & 11 & 11 & 11 & 11 & 11 & 11 & 11 \\
\hline \multirow[t]{2}{*}{$\mathrm{Si}(\mathrm{L})$} & $r$ & -0.16 & 0.19 & 0.35 & 0.25 & -0.35 & 0.06 & -0.16 \\
\hline & $n$ & 15 & 15 & 15 & 15 & 15 & 14 & 15 \\
\hline \multirow[t]{2}{*}{ Si (M\#1) } & $r$ & 0.23 & -0.32 & -0.46 & -0.34 & -0.23 & -0.48 & 0.23 \\
\hline & $n$ & 18 & 18 & 18 & 18 & 18 & 17 & 18 \\
\hline \multirow[t]{2}{*}{ Si (M\#2) } & $r$ & -0.16 & 0.02 & 0.17 & 0.15 & 0.06 & 0.24 & -0.16 \\
\hline & $n$ & 17 & 17 & 17 & 17 & 17 & 16 & 17 \\
\hline \multirow[t]{2}{*}{$\mathrm{Si}(\mathrm{H})$} & $r$ & 0.04 & -0.22 & -0.28 & -0.18 & 0.04 & 0.01 & 0.04 \\
\hline & $n$ & 11 & 11 & 11 & 11 & 11 & 10 & 11 \\
\hline
\end{tabular}




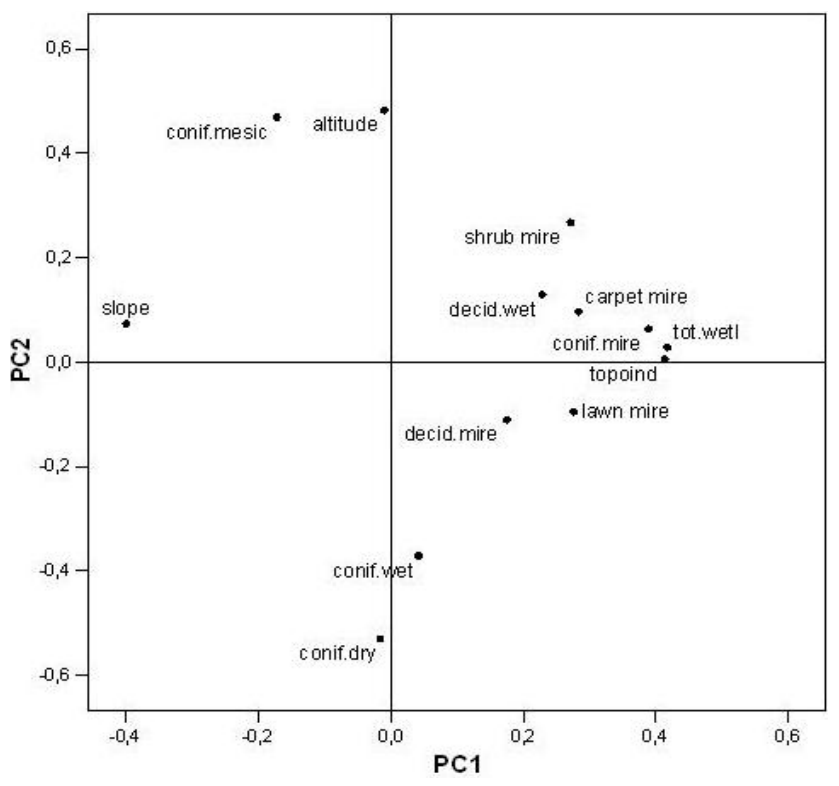

Fig. 8. PCA analysis of the most significant topographic and vegetation variables. The axes represent loadings for PC1 and PC2. The topographic variables included were mean altitude, mean slope and mean TWI. The vegetation variables were total wetland and variables no. 1-2, 4-5 and 7-11 in Table 3 (calculated as percentages of each catchment).

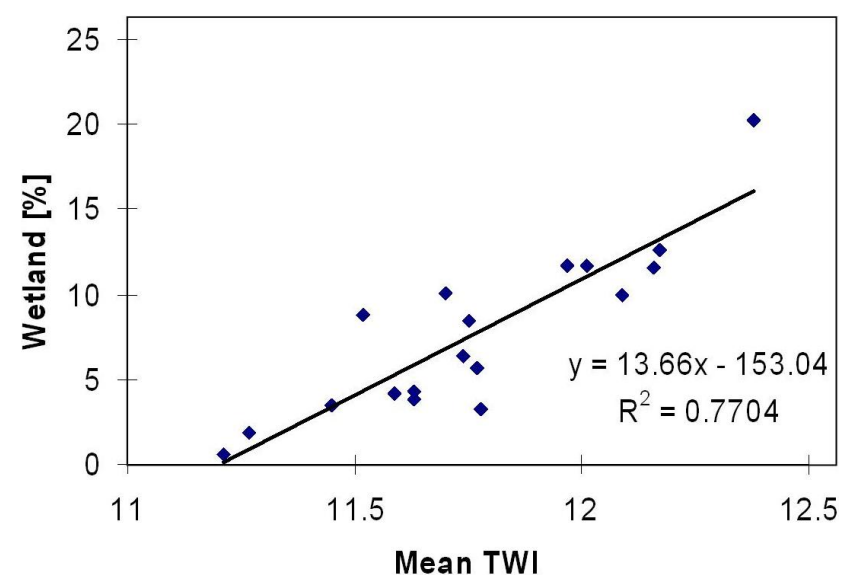

Fig. 9. Relationship between mean TWI and wetland percentage.

\subsection{Relations between topography-wetland-mires classes and water chemistry}

A correlation analysis including topography, wetland percentages and water chemistry (Table 8) showed moderate and strong pair-wise correlations between topography-wetland (as mentioned above), wetland-chemistry and topographychemistry. The chemistry referred to here is DOC- and Feconcentration during medium and high flow.

The classification of wetlands into bogs and fens did not give any stronger correlations in relation to water chemistry
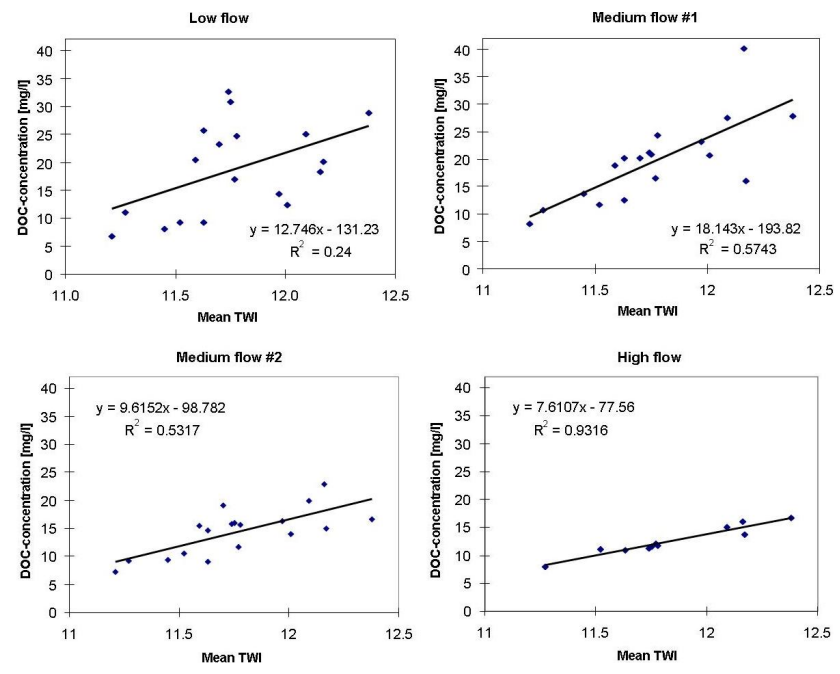

Fig. 10. Regressions between mean topographic wetness index and DOC in the four flow situations.

(Table 8). The class Mixed mire had stronger correlations than Fen and Bog.

Si was not significantly correlated to topography or wetland.

There were strong correlations between mean topographic wetness index and DOC-concentration (Table 8, Fig. 10). It was strongest at the high flow situation and decreasing with decreasing flow. The fact that mean TWI gave the strongest correlation can be explained by that it includes other surfaces with peat layers than only mapped mires, e.g. so called cryptic wetlands.

\section{Discussion}

Is it possible to predict stream water chemistry by analyzing official maps and map data? This question would probably get a negative answer from many researchers. With respect to the complexity and high number of relationships and varied landscape elements that influence stream water chemistry, several of them are not covered by available official maps and map data. The maps are also, in general, too coarse compared to the scale of most process studies. The results of this study, however, where catchments in the scale 1$4 \mathrm{~km}^{2}$ were investigated, show that official topographic maps and elevation data (50 $\mathrm{m} \mathrm{DEM}$ ) can be used for prediction of DOC-concentration at four different flow situations. Other variables measured, such as concentrations of $\mathrm{Fe}, \mathrm{Al}$ and $\mathrm{Si}$, did not show the same clear relations at all flow situations, probably because they are more closely related to the geology, which was not included in the map data. The elevation data, recalculated as mean slope and mean TWI, showed very strong correlations with DOC-concentration, increasing with increasing flow. Mean slope and mean TWI are measures of the catchment's topographic characteristics, which 
explain to what extent the groundwater is fluctuating at or near the ground surface where many chemical processes take place. Using the mean values makes random errors in the map information less important.

In addition to topographic map data, wetland data were also useful in predicting stream water chemistry. Both topography and wetland variables were more strongly correlated to water chemistry at medium (summer and autumn) and high flow (spring flood) than they were at low flow (summer). This indicated that, within the $120 \times 50 \mathrm{~km}$ region, the connection between the sources of dissolved organic carbon and the stream was weaker during low flow. One possible reason was the longer retention times for water in the ground and streams which could give more time for biological degradation of organic matter. The low flow situation also occurred during summer when the biological activity was high.

The vegetation map data did not add much to the results, even if there were some significant correlations with water chemistry variables. The vegetation database was, however, useful for validation of the topographic map data that were produced by interpretation of black and white aerial photos taken from a higher altitude, and thus less accurate, especially fuzzy objects like wetlands. Our findings are contradictory to the statement by Rodhe and Seibert (1999) that good maps over mires already exist.

This study includes catchments larger in scale, from 0.5 1.5 to $1-4 \mathrm{~km}^{2}$, compared to the previous study by Andersson and Nyberg (2008). A comparison showed a substantially larger variation in water chemistry for smaller catchments, which supports the results in other similar studies (e.g. Wolock et al., 1997). That is probably the main reason for the stronger correlations between percentage wetland, mean slope and mean TWI vs. DOC-concentration at the larger scale.

It is widely recognized that topographic analyses are sensitive to the resolution of the data source used. This affects all topographic attributes, but in varying ways. The resolutiondependence of slope and specific catchment area has been most intensively studied because of their regular application in hydrological modelling. In this study a $50 \mathrm{~m}$ DEM grid was used for deriving the variables slope and topographic wetness index. Beven (1997) criticized modellers deriving topographic indices from DEMs with grid sizes exceeding slope lengths in the landscape. In our study the comparison between TWI grid with the wetland layer was not a success when considering spatial location and distribution. However, mean values seem to be useful in regression analyses.

In a few years time, official high-resolution laser-based elevation data will be available. If DEM's with different grid resolution show considerable differences in the TWI pattern, further studies of catchments would be of interest. The algorithm used for calculating the TWI is also crucial, and different types should be tested in a similar way, in order to find the best method for prediction of water chemistry at different catchment scale ranges.
There is still a large gap between process knowledge in small versus large hydro-chemical scales. Many studies have been carried out in few and small catchments, where it has been possible to measure and control many spatial and temporal variables with high accuracy. Environmental institutes and agencies are, however, in need of simple and cost efficient methods for monitoring stream water chemistry. Therefore, studies of the potential to use official map data in the up-scaling of local process knowledge are of crucial importance.

\section{Conclusion}

Official map data could be used for predictions of DOCconcentration in boreal headwater catchments. This conclusion was supported by strong correlations between mean wetland percent, mean slope, mean topographic wetness index and DOC-concentration for different flow situations at different seasons. Mean TWI gave the strongest correlation, which shows that the relatively coarse elevation data $(50 \mathrm{~m}$ DEM) can be used for predictions of DOC-concentration in boreal catchments in the range of $1-4 \mathrm{~km}^{2}$.

Acknowledgements. The authors wish to thank Mistra (The Foundation for Strategic Environmental Research) and the multidisciplinary research group MiljöFoCus at Karlstad University for funding. Maria Malmström is gratefully thanked for her work with chemical analyses.

Edited by: S. Uhlenbrook

\section{References}

Andersson, J. O. and Nyberg, L.: Spatial variation of wetlands and flux of dissolved organic carbon in boreal headwater streams, Hydrol. Proc., 22, 1965-1975, 2008.

Beven, K. J. and Kirkby, M. J.: A physically based, variable contributing area model of basin hydrology, Hydrol. Sci. Bull., 24, 43-69, 1979.

Beven, K. J.: Hillslope runoff processes and flood frequency characteristics. In Abrahams AD (ed.). Hillslope Processes, Allen and Unwin, Boston, USA, 187-202, 1986.

Beven, K. J.: Topmodel: a critique, Hydrol. Proc., 11, 1069-1085, 1997.

Bishop, K. H., Petterson, C., Allard, B., and Lee, Y. H.: Identification of the riparian sources of aquatic dissolved organic carbon, Environ. Int., 20(1), 11-19, 1994.

Blöschl, G.: Scaling in hydrology, Hydrol. Proc., 15, 709-711, 2001.

Blöschl, G. and Sivapalan, M.: Scale issues in hydrological modelling: A review, Hydrol. Proc., 9 (3-4), 251-290, 1995.

Clair, T. A., Pollock, T. L., and Ehrman, J. M.: Exports of carbon and nitrogen from river basins in Canada's Atlantic provinces, Global Biogeochem. Cy., 8, 441-450, 1994.

Creed, I. F., Sanford, S. E., Beall., F. D., Molot, L. A., and Dillon, P. J.: Cryptic wetlands: integrating hidden wetlands in regres- 
sion models of the export of dissolved organic carbon from forest landscapes, Hydrol. Proc., 17, 3629-3648, 2003.

Dillon, P. J. and Molot, L. A.: Effect of landscape form on export of dissolved organic carbon, iron, and phosphorus from forested stream catchments, Water Resour. Res., 33, 2591-2600, 1997.

Eckhardt, B. W. and Moore, T. R.: Controls on dissolved organic carbon concentrations in streams, southern Quebec, Canad. J. Fish. Aquat. Sci., 47, 1537-1544, 1990.

Freeman, C., Gresswell, R., Lock, M. A., Swanson, C., Guasch, H., Sabater, F., Sabater, S., Hudson, J., Hughes, S., and Reynolds, B.: Climate change: Mans indirect impact on wetland microbial activity and the biofilms of a wetland stream, in: Man's Influence on Freshwater Ecosystems and Water Use, Int. Assoc. Hydrol. Sci. Publ., 230, 199-206, 1995.

Güntner, A., Seibert, J., and Uhlenbrook, S.: Modelling spatial patterns of saturated areas: An evaluation of different terrain indices, Water Resour. Res., 40, 2004.

Hemond, H. F.: Wetlands as the source of dissolved organic carbon to surface waters, Organ. Acid. Aquat. Ecosyst., 301-131, 1990.

Hooper, R. P.: Applying the scientific method to small catchment studies: a review of the Panola Mountain experience, Hydrol. Proc., 15, 2039-2050, 2001.

Hope, D., Billett, M. F., and Cresser, M. S.: A review of the export of carbon in river water: fluxes and processes. Environmental Pollution, 84, 301-324, 1994.

Köhler, S., Hruska, J., and Bishop, K.: Influence of organic acid site density in $\mathrm{pH}$ modeling of Swedish lakes, Canad. J.Fish. Aquat. Sci., 56(8), 1461-1470, 1999.

Koprivnjak, J.-F. and Moore, T. R.: Sources, sinks, and fluxes of dissolved organic carbon in subarctic fen catchments, Arct. Alp. Res., 24, 204-210, 1992.

Lundegårdh, P. H.: Beskrivning till berggrundskartan över Värmlands län: östra och mellersta Värmlands berggrund: fyndigheter av nyttosten och malm i Värmlands län. Serie Ba, Översiktskartor med beskrivningar, 45:1/03732657 (in Swedish), Sveriges Geologiska Undersökning, Stockholm, Sweden, 1995.

Lundin, L.: Effects on hydrology and surface water chemistry of regeneration cuttings in peatland forests. Int. Peat J., 9, 118-126, 1999.

Lundqvist, J.: Studies of the quaternary history and deposits of Värmland, Sweden, Swedish Geological Survey, Yearbook, 52(2), Stockholm, Sweden, 1958.

Lundqvist, J.: Beskrivning till karta över landisens avsmältning och högsta kustlinjen i Sverige. (in Swedish). Sveriges Geologiska Undersökning, Stockholm, Sweden, ser Ba nr. 18, 1961.

Lundström, U., Nyberg, L., Danielsson, R., van Hees, P., and Andersson, M.: Forest soil acidification: Monitoring on the regional scale exemplified in Värmland, Sweden, Ambio, 27(7), 551-556, 1998.

Löfgren, S., Andersen, T., and Forsius, M.: Climate induced water color increase in Nordic lakes and streams due to humus, Nordic Council of Ministry brochure, 2003.

Löfroth, M.: Våtmarkerna och deras betydelse. Rapport 3824 (in Swedish). Naturvårdsverket, Solna, Sweden, 1991.

McGuire, K. J., Mc Donnel, J. J., Weiler, M., McGlynn, B. L., Welker, J. M., and Seibert, J.: The role of topography on catchment-scale water residence time, Water Resour. Res., 41, W05002, doi:10.1029/2004WR003657, 2005.

Monteith, D. T., Stoddard, J. L., Evans, C. D., de Wit, H. A., For- sius, M., Høgasen, T., Wilander, A., Skjelkvale, B. L., Jeffries, D. S., Vuorenmaa, J., Keller, B., Kopacek, J., and Vesely, J.: Dissolved organic carbon trends resulting from changes in atmospheric deposition chemistry. Nature, 450, 537-540, 2007.

Moore, I. D., Grayson, R. B., and Landson, A. R.: Digital Terrain Modelling: a Review of Hydrological, Geomorphological, and Biological Applications, Hydrol. Proc., 5, 3-30, 1991.

Moore, I. D., Lewis, A., and Gallant, J. C.: Terrain attributes: Estimation methods and scale effects, in: Modelling Change in Environmental Systems, edited by: Jakeman, A. J., Beck, M. B., and McAleer, M., John Wiley \& Sons Ltd, Chapt. 8, 1993.

Moore, T. R.: Dissolved organic carbon: sources, sinks, and fluxes and role in the soil carbon cycle. In Soil Processes and the Carbon Cycl., Lal, R., Kimble, J. M., Follett, R. F., and Stewart, B. A., Adv. Soil Sci., CRC press, Boca Raton, FL, USA, 281-292, 1998.

Mulholland, P. J. and Kuenzler, E. J.: Organic carbon export from upland and forested wetland watersheds, Limnol. Ocean., 24, 960-966, 1979.

Mulholland, P. J.: Dissolved organic matter concentration and flux in streams, J. North Am. Benthol. Soc., 16, 131-141, 1997.

Nyberg, L.: Soil- and groundwater distribution, flowpaths and transit times in a small till catchment. PhD Thesis, Uppsala University, Sweden, 1995.

O'Callaghan, J. F. and Mark, D. M.: The extraction of drainage networks from digital elevation data, Comput. Vis. Graph. Image Proc. 28, 323-344, 1984.

Quinn, P. F., Beven, K. J., and Lamb, R.: The $\ln (\mathrm{a} / \tan \beta)$ index: how to calculate it and how to use it in the TOPMODEL framework, Hydrol. Proc., 9, 161-182, 1995.

Rodhe, A. and Seibert, J.: Wetland occurrence in relation to topography - a test of topographic indices as moisture indicators, Agr. For. Meteor., 98-99, 325-340, 1999.

Raab, B. and Vedin, H.: Klimat, sjöar och vattendrag. Sveriges Nationalatlas (in Swedish), SNA förlag, Stockholm, Sweden, 1995.

Rosén, K., Aronson, J. A., and Eriksson, H. M.: Effects of clearcutting on stream water quality in forest catchments in central Sweden, For. Ecol. Manag., 83(3), 237-244, 1996.

SEPA: Natural acidification only, Report 5317 (in Swedish with English summary), Swedish Environmental Protection Agency, Stockholm, Sweden, 2003.

SNV: Miljökvalitetsnormer för flöden/nivåer i rinnande vatten, Redovisning av ett regeringsuppdrag, Rapport 5292 (in Swedish), Naturvårdsverket, 2003.

Sivapalan, M. and Kalma, J. D.: Scale problems in hydrology: Contributions of the Robertson workshop, Hydrol. Proc., 9(3-4), 243-250, 1995.

Tarboton, D. G.: A new method for the determination of flow directions and upslope areas in grid digital elevation models, Water Resources Research, 33, 309-320, 1997.

Tranvik, L. J., Jansson, M., Evans, C. D., Freeman, C., Monteith, D. T., Reynolds, B., and Fenner, N.: Climate Change: terrestrial export of organic carbon, Nature, 415, 861-862, 2002.

Wolock, D. M., Hornberger, G. M., Beven, K. J., and Campbell, W. G.: The relationship of catchment topography and soil hydraulic characteristics to lake alkalinity in the north eastern United States, Water Resour. Res., 25, 829-837, 1989.

Wolock, D. M., Hornberger, G. M., and Musgrove, T. J.: Topographic effects on flow path and surface water chemistry of the 
Llyn Brianne catchments in Wales, J. Hydrol., 115, 243-259, 1990.

Wolock, D. M. and Price C. V.: Effects of digital elevation model map scale and data resolution on a topography-based watershed model, Water Resour. Res., 30(11), 3041-3052, 1994.

Wolock, D. M., Fan, J., and Lawrence, G. B.: Effects of basin size on low-flow stream chemistry and subsurface contact time in the Neversink river watershed, New York, USA, Hydrol. Proc., 11, 1273-1286, 1997.
Worrall, F., Burt, T., and Adamson, J.: Can climate change explain increases in DOC flux from upland peat catchments?, Sci. Total Environ., 326, 95-112, 2003.

Zhang, W. and Montgomery, D. R.: Digital elevation model grid size, landscape representation, and hydrologic simulations, Water Resour. Res., 30(4), 1019-1028, 1994. 